\title{
Histopathological Changes Induced by Metaldehyde in Eobania vermiculata
} (Müller 1774)

\author{
Yasser Abo Bakr ${ }^{1}$
}

\begin{abstract}
Metaldehyde is a specific molluscicide for terrestrial snails and slugs. Histopathological changes induced by metaldehyde in the terrestrial snail $E$. vermiculata were investigated by light microscopy in order to study its cellular toxicity. Alterations in digestive gland included cellular infiltration, destruction of intertubular connective tissue, and extensive vacuolation in the cytoplasm of digestive cells. Degeneration and necrosis in the lining epithelium of the digestive tubules were also noticed. Irregular thickening in the outer covering muscular layer, thinning of basal layer, atrophy and degeneration of mucous cells were the most observed changes in dart gland. The histological alterations in the kidney were degeneration of nephrocytes, and an increase in the number and size of concretions in nephrocytes. Metaldehyde showed cytotoxic effects in all tested organs, that in turn leads to failure of the digestive, reproductive and excretory systems.
\end{abstract}

Key words: Metaldehyde, Eobania vermiculata, digestive gland, dart gland, kidney.

\section{INTRODUCTION}

Terrestrial molluscs are currently considered a significant threat to sustainable agriculture in many parts of the world (Barker, 2002). They are major pests of a wide range of agricultural and horticultural crops in temperate and humid habitats world-wide (Godan, 1983; Speiser and Kistler, 2002). Economic damage caused by these molluscs is due to feeding and to contamination with their bodies, faeces or slime, leading to deterioration of the product quality, in addition to the financial loss (Iglesias et al., 2003). In Egypt, terrestrial snails damage vegetables, field crops, orchard trees as well as ornamental and medical plants (Bishara et al., 1968; El-Okda, 1980; El-Wakil et al., 2000). The terrestrial helicid snail Eobania vermiculata Müller was surveyed as agricultural economic pest in Egypt since the 1960s up to now (Kassab and Daoud, 1964; ElOkda, 1979; Abo Bakr, 1997; Eshra 2004). Moreover, E. vermiculata was recorded as an intermediate host of the animal nematode Angiostrongylus cantonensis (Aly and Sleem, 2000).

Chemical control with high concentrations of molluscicides is the main method for controlling terrestrial gastropod pests (Godan, 1983; Coupland,
1996; Abdallah et al., 1992, 1998; El-Shahaat et al., 2007, 2009). The most important advance in chemical control of terrestrial molluscs was made with the unexpected discovery, c.1934 in South Africa, of the molluscicidal properties of metaldehyde, a solid polymer of acetaldehyde and 6 years later was the most popular and generally recommended poison bait for use against terrestrial gastropod pests (Gimingham, 1940; Henderson and Triebskorn, 2002).

In the Egyptian control program of land mollusks, high concentration of the carbamate insecticide methomyl ( $2 \%$ a.i) in wheat bran bait is the main chemical control method of terrestrial snails and slugs (Ministry of Agriculture and Land Reclamation, 2001), which presents bad adverse effects to non-target organisms of mammals, birds, honey-bees and wild life (IPCS, 1996). Metaldehyde is perceived to dehydrate snails and slugs. Consequently, it is assumed that on raining, for instance, the loss of body fluid is made up and its effect is impaired. But findings of Triebskorn $e t$ al. (1998) have shown that is just a hypothetical explanation for mode of action, leading to the incorrect conclusion that the effect of metaldehyde is reduced under damp or wet conditions.

Most molluscicide research is restricted to $\mathrm{LD}_{50}$ tests, which provide information about lethal or nonlethal effects. Such tests however, do not yield any further information about either the targets for the molluscicides or the mollusc-specific mechanisms induced in the snails' bodies. This knowledge is essential for the development of new more selective substances, so much basic research is required. Little is known about the mollusc-specific effects of metaldehyde and details of its exact mechanism of action by which it causes snail or slug death are still unknown (Triebskorn and Künast, 1990 and Henderson and Triebskorn, 2002).

The present study is an attempt to study toxic action of metaldehyde at cellular level of different organs which represent different systems in terrestrial gastropods. So, the influence of low concentration (1\%) of metaldehyde on the tissues of digestive gland, dart gland and kidney that represent digestive, reproductive and excretory systems respectively was investigated by light microscopy.

\footnotetext{
${ }^{1}$ Department of Agricultural Animal Pests, Plant Protection

Research Institute, Agricultural Research Center, Alexandria, Egypt.

E-mail: yasserabubakr@yahoo.com

Received August 14, 2011, Accepted September4, 2011
} 


\section{MATERIALS AND METHODS}

Snails: Adult specimens of terrestrial helicid snail $E$. vermiculata were collected randomly by hand picking from Abbis region, Alexandria city $\left(3122^{\circ} \mathrm{N}: 2992^{\circ}\right.$ E), northern Egypt. They were brought to laboratory and each snail was weighed to the nearest $0.1 \mathrm{~g}$ and snails weighing $3 \pm 0.2 \mathrm{~g}$ were used. Acclimatization of snails to laboratory conditions $\left(22 \pm 2^{\circ}\right.$ and $14 \mathrm{~h}$ light: $10 \mathrm{~h}$ dark photoperiod) in a glass terrarium lasted 2 weeks. They were fed daily fresh lettuce leaves ad libitum.

Molluscicide treatment: Snails were divided into 2 groups, treated and control. Animals of treated group were exposed to wheat-bran bait formulation containing $1 \%$ metaldehyde (2, 4, 6, 8-tetramethyl-1, 3, 5, 7tetraoxacyclo-octane) with molecular formula $\mathrm{C}_{8} \mathrm{H}_{16} \mathrm{O}_{4}$. Control group animals were exposed to molluscicidefree wheat-bran bait. After 24 hours of exposure, ten animals of each group were randomly selected for dissection and light microscopy examination.

Preparation for histological analysis: Snail's shell was broken carefully and the soft specimen was quickly dissected. Digestive gland, kidney and the auxiliary copulatory organ glands of control as well as treated snails were isolated and immediately fixed in 10\% formalin solution for 10 hours. The fixed tissues were dehydrated in a series of ethyl alcohol then cleared in xylene and embedded in paraffin wax. The paraffin blocks were sectioned at $3 \mu \mathrm{m}$ thickness by slide microtome. The obtained tissue sections were collected on glass slides and stained by hematoxylin and eosin stain (Banchroft et al., 1996) for histopathological examination by the light microscope.

\section{RESULTS}

The digestive gland of control group: The digestive gland of the terrestrial snail E. vermiculata is a big bilobed mass which opens into the stomach by two hepatic ducts. Examination of the serial prepared sections of each lobe of this gland revealed that, it consists of numerous digestive tubules (Fig.1a). Each digestive tubule is surrounded by a layer of connective tissue that appears as white adipose tissue. This tissue composed of adipocytes whose nuclei compressed and displaced to one side by the stored droplet and the cytoplasm is reduced to a small rim around the periphery (Fig.1b). Few muscle fibers can be observed around the tubules (Fig.1b). The digestive tubules are lined with columnar cells resting on a thin basement membrane (Fig.1b). These cells can be differentiated into three different types of cells: digestive cells, calcium cells and excretory cells. Digestive cells are the most frequent cell type and they are usually columnar in shape, but vary in size. These cells are characterized by numerous cytoplasmic granules. Round and small nuclei are basally located in this type of cells (Fig.1c). The second cell type in the digestive gland epithelium lining the tubules is calcium cells. They are characterized by their pyramidal shape and the presence of calcium granules. These cells are fewer in number than digestive cells (Fig.1c). The third cell type is the excretory cells which are larger in size than digestive cells and appear ovoid in shape. They have small, flattened and basal nuclei and the cytoplasm of which is occupied by a main large vacuole that contain small granules as shown in Fig. (1c).

Treated snails: Most of digestive gland cells showed histopathological changes after 24 hours of exposure to $1 \%$ metaldehyde. Their cellular outline was abnormal. Different pathological alterations were observed in the connective tissue as well as the tubular epithelium. Cellular infiltration was observed in the destructed intertubular connective tissue (Fig.1d). The irregular shape of the tubules and enfolding in tubular membrane displayed abnormal morphological changes (Fig.1d). Effect of metaldehyde on the tubular epithelium is characterized by the development of extensive vacuolation in the cytoplasm of digestive cells (Fig.1e). Large amount of residual bodies are randomly distributed in the vacuoles of excretory cells (Fig.1e). Degeneration and necrosis in the lining epithelium of the digestive tubules were also noticed (Fig.1f).

The dart glands of control snails: The dart glands of auxiliary copulatory organ are pair of tufted tubular mucous glands which open into the vagina. In control snails, branching glandular structure was observed in light microscopy. This glandular structure consists of normal muscular outer covering surface (Fig.2a); large numbers of mucous secretory cells (Fig.2a); as well as a thick basal cell layer (Fig.2b).

Treated snails: The branching glandular structure of dart glands of metaldehyde-treated snails showed some pathological alterations. Abnormal irregular thickening in the outer covering muscular layer was observed as shown in Fig. (2c), while the basement cell layer became very thin compared to control snails (Fig.2d). Most of mucous cells were abnormal by virtue of their atrophy and reduction of their numbers and sizes (Fig.2e). Degenerated mucous cells as well as focal pigmentation were also noticed (Fig. $2 \mathrm{f}$ and g).

Kidney of control animals: The kidney of $E$. vermiculata is a single elongated triangular spongy mass which hangs down from the roof of the long to the right of the pericardium. It consists of a tubule enclosing a luminal cavity derived from the coelom. There are many large folds on the walls of the kidney which project into its lumen. A continuous epithelium of columnar cells, 
the nephrocytes, lines the whole inner surface of the kidney (Fig.3a). The apical portion of the nephrocytes consists of vacuoles in which excretory products accumulate as large concretions. The nuclei are oval and basal in position (Fig.3 b). Underlying the epithelium there is a sparse layer of connective tissue as shown in Fig. 3b.
Treated snails: The kidney of metaldehyde-treated snails was influenced by this treatment. Degeneration of some nephrocytes occurred as shown in Fig. 3c. Hyalinization in fibrous connective tissue was noticed (Fig. 3d). Heavy and massive production of concretions was observed in nephrocytes, in addition to an enlargement of these concretions size compared to control snails (Fig.3e and f). The concretions occupied almost the entire anterior of the nephrocytes.
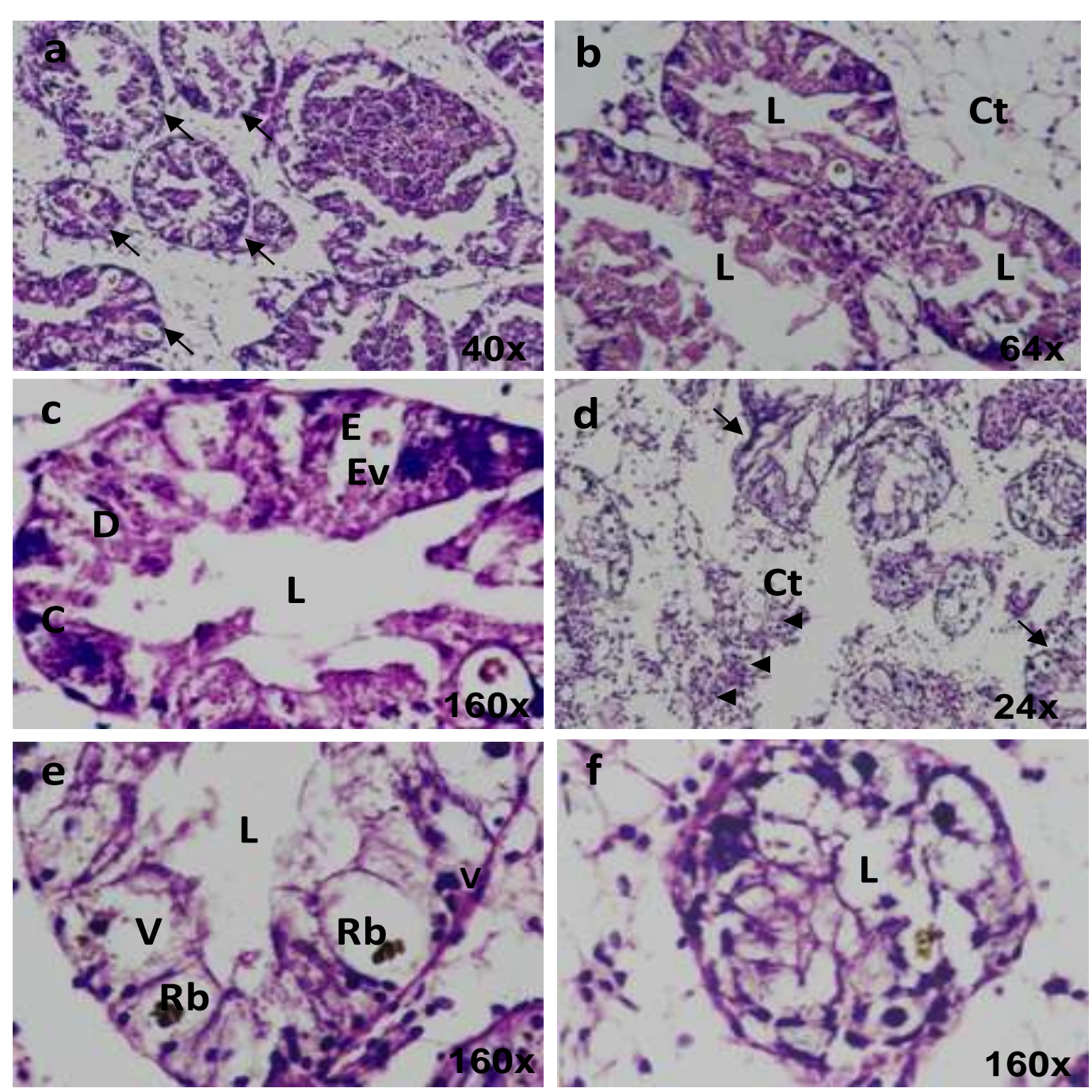

Fig. 1. Light micrographs of transvers sections of digestive gland of $E$. vermiculata stained with haematoxylin and eosin. (a-c) Control group showing normal histological structure. (a) Digestive tubules (arrows). (b) Lumen of tubules (L); intertubular connective tissue $(\mathrm{Ct})$ and muscle fibers (Mf). (c) Digestive cells (D); Calcium cells (C); excretory cells (E); excretory vacuoles (Ev) and lumen (L). (d-f) Metaldehyde-treated group showing pathological changes. (d) Cellular infiltration (arrowheads) in destructed intertubular connective tissue (Ct) and enfolding in tubular membrane (arrows). (e) Vacuolation in the cytoplasm of digestive cells (V) and increased amount of residual bodies (Rb) in excretory vacuoles. (f) Degeneration and necrosis of most lining epithelial cells of digestive tubule 

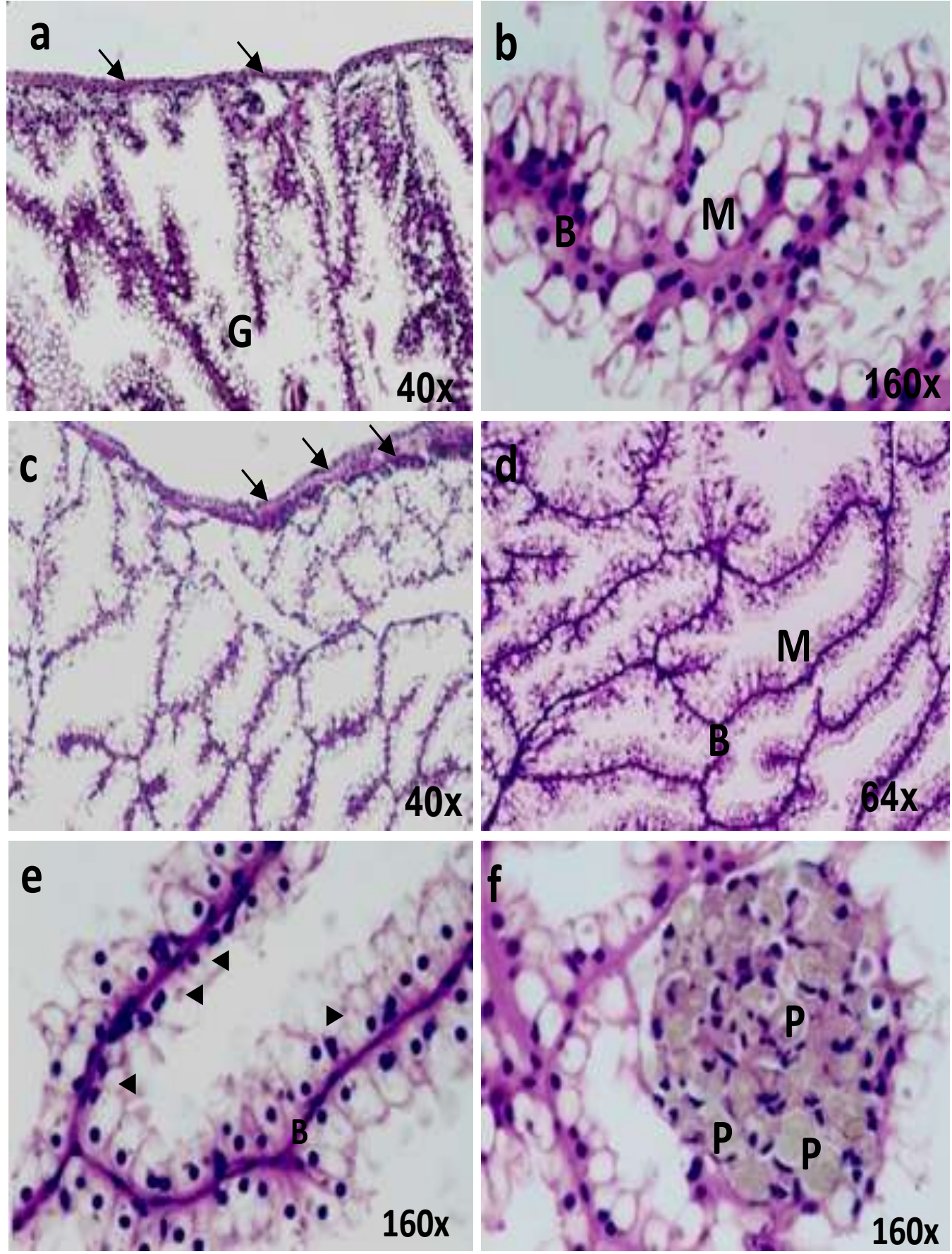

Fig. 2. Light micrographs of transverse sections of mucous dart gland of $E$. vermiculata stained with haematoxylin and eosin. (a and b) Control group showing normal histological structure. (a) Normal muscular outer covering surface (arrows) with branching glandular structure (G). (b) A large number of mucous secretory cells (M) with a thick basal layer (B). (c-f) Metaldehyde-treated group showing pathological changes. (c) Irregular thickening in the outer covering muscular layer (arrows). (d) Thinning of basal cellular layer (B); atrophy and reduction in the number of mucous cells $(M)$. (e) Degenerated mucous cells (arrowheads) and thin basal cellular layer (B). (f) Focal pigmentation (P). 

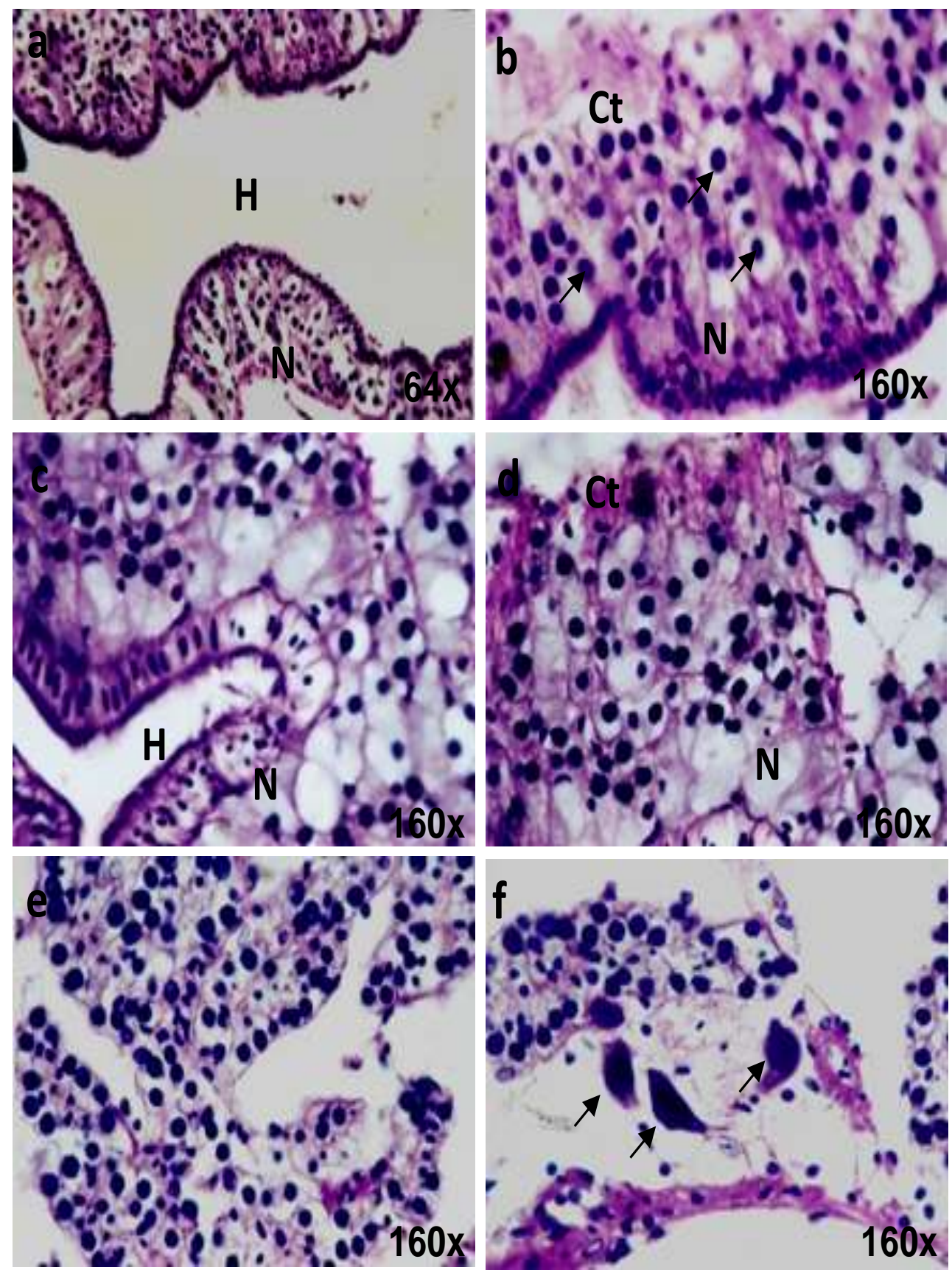

Fig 3. Light micrographs of transverse sections of the kidney of $E$. vermiculata stained with haematoxylin and eosin. (a and b) Control group showing normal histological structure. (a) A continuous epithelium of columnar cells, the nephrocytes $(N)$ lines the whole inner hemolymphatic space (H). (b) Apical portion of the nephrocytes $(\mathrm{N})$ consists of vacuoles in which excretory products accumulate as concretions (arrows) and normal connective tissue ( $\mathrm{Ct}$ ). (c-f) Metaldehyde-treated group showing pathological changes. (c) Degeneration of nephrocytes (N). (d) Hyalinization in fibrous connective tissue $(\mathrm{Ct})$. (e) Massive number of concretions. (f) Intensive staining of large concretions (arrows) 


\section{DISCUSSION}

The digestive gland (also known in the literature as mid gut gland, hepatopancreas and liver) of gastropods is the largest organ in their body. It consists of tow lobes communicating with the gastric pouch via large ducts, which branch to form smaller ducts, ductules and complex branched blind tubules (Dimitriadis, 2001). This description is identical to our observation of E. vermiculata digestive gland. Three cell types of digestive gland tubules namely digestive cells, calcium cells and excretory cells were observed in the present study. The same cell types were described for the same snail species (Mersal, 1990 and Aioub et al., 2000) and for Deroceras reticulatum (Babua and SkowronskWendland, 1988). Beshr (2000) reported that there are 3 cell types, digestive (with 2 phases, digestive and excretory), basophilic and thin cells; while Heiba et al. (2002) described 3 cell types namely; digestive, secretory and excretory cells for $E$. vermiculata digestive gland. In spite of the numerous studies on the morphology and physiology of gastropods digestive gland cells, there is little agreement about number, nomenclature and function of cell types that constitute the digestive gland epithelium. Tow cell types namely: digestive cells and basophilic cells were described in the digestive gland of E. vermiculata and Littorina littorea (Saad and Farag, 1988 and Zaldibar et al., 2007). However, digestive and excretory cells have been observed in E. vermiculata (Al-Zahaby et al., 1993). Most findings are consistent with the hypothesis that the digestive gland epithelium of terrestrial gastropods is composed of three cell types: digestive cells, calcium cells and excretory cells (Babua and SkowronskWendland, 1988; Mersal, 1990; Aioub et al., 2000; Dimitriadis, 2001; Chabicovsky et al. 2004 and Snyman et al., 2005). The presence of fourth type, the thin cells, have been documented in $H$. aspersa, A. reticulatus and E. vermiculata (Sumner, 1965, 1969; Walker, 1970; Beshr, 2000 and Hamed et al., 2007). The digestive gland of gastropods is concerning with production of digestive enzymes, adsorption of nutrients, endocytosis of food substances, food storage and excretion (Dimitriadis, 2001). Also, it plays an important role in biotransformation, detoxification and excretion of xenobiotics. So, it is one of the most important target organs for toxic injury. The present study clearly demonstrates several pathological changes in the digestive gland of metaldehyde-treated $E$. vermiculata after $24 \mathrm{~h}$ of exposure. Extensive cytoplasmic vacuolation was developed in the digestive cells. This corroborates the investigations of Hamed et al. (2007) who reported severe cytoplasmic vacuolation in digestive cells of E. vermiculata treated with molluscicidal carbamates; methiocarb and methomyl. This observation was explained by Triebskorn and Künast (1990) who attributed increasing the number of large vacuoles to the intensified fusion between small and large vacuoles. The irregular shape of the tubules or alteration of the general cells outline was another toxic impact. This change might result from the interaction of the lipophilic molluscicide with membranes as consequence of direct contact of toxin and cell surfaces. This interaction might induce changes in composition, fluidity and stability of membranes (Moore, 1982 and 1985). The effect of metaldehyde on the digestive gland of E. vermiculata resulted in an obvious destruction of the intertubular connective tissue. This in accordance with Hamed et al. (2007) who stated that carbamate molluscicides induced extensive destruction and disorganization of intertubular connective tissue, folding of basement membrane and detachment of tubular epithelium from basal lamina. Also, Triebskorn and Künast (1990) reported that carbamate molluscicides caused gaps between the basal parts of the epithelial cells and the underlying connective and muscle tissues. Cellular infiltration in the destructed intertubular connective tissue was another pathological effect of metaldehyde to this tissue. This effect has also been reported previously in the digestive gland of Monacha obstructa treated with methomyl (Zedan et al., 1999); E. vermiculata exposed to oxamyl and furathiocarb (Aioub et al., 2000 and Beshr, 2000); Galba truncatula treated with thiodan (Cengiz et al., 2005) and E. vermiculata exposed to methiocarb (Hamed et al., 2007). Metaldehyde induced degenerative effect in the digestive gland cells. This in agreement with the results of Triebskorn (1991) who reported also degenerative effects in the hepatopancreas cells of Deroceras reticulatum exposed to metaldehyde. The molluscicidal active carbamate compounds, aldicarb and methomyl, caused the same degenerative effect in the digestive gland of E. vermiculata and T. pisana (Zaalouk, 2003 and Radwan et al., 2008). Necrosis in the lining epithelial cells in some digestive tubules was observed in present study. Triebskorn et al. (1998) reported that, necrosis was observed in the skin of $D$. reticulatum after oral or dermal application of metaldehyde.

The toxic effect of molluscicides on the reproductive organs is central to management gastropod pest species. Although the biology of the reproductive system of pulmonate gastropods has been well studied (Boycott, 1917; Lind, 1973; Baur, 1988; Gómez, 1991; Haas and Baur, 1995; Adamo and Chase, 1996 and Egonmwan, 2007), few studies have investigated the structure and 
function of the dart gland (also known in literature as mucous gland of auxiliary copulatory organ or digitiform glands) (Gómez et al., 1996; Koene and Chase, 1998 and Chase and Blanchard, 2006). The reproductive system of $E$. vermiculata as well as many stylommatohporans equipped with an auxiliary copulatory organ that plays an active role in mating. This organ is equipped with a sharp calcareous dart (known in literature as love-dart) within a so-called dart sac (Koene and Schulenburg, 2005). A pair of tufted tubular mucous glands opens to the sac. This configuration is a feature common in helicoidean families, where the organ is placed on the vagina (Gómez, 2001). The mucus from this gland is secreted in the passage way through the dart passes on its way out of the shooting animal. The morphology of the dart suggests that it adapted to carry a maximal load of mucus (Koene and Schulenburg, 2005). Koene and Chase (1998) reported that, the dart carries approximately $2 \mathrm{mg}$ of white mucus secreted by a pair of digitiform glands. Koene and Chase (1998) discovered that the dart gland mucus induced muscular contractions in the snail's spermatophore-receiving organs of the female reproductive tract. These contractions reconfigured the organs in such a manner as to allow allosperm to escape enzymatic digestion and proceed to the spermathecal storage sacs. On an average, about 99.98\% of transferred sperm are digested in the bursa copulatrix before they reach the spermathecal sacs (Rogers and Chase, 2001). Chase and Blanchard (2006) supported the hypothesis that the dart transfers a substance via the mucus capable of reconfiguring the spermatophore-receiving organs and it may be a peptide. The delivered mucus via love-dart thought to play a key role in increasing paternity (Landolfa et al., 2001 and Chase and Blanchard, 2006). Our histological examination is in accordance that of Gómez et al. (1996) who reported that the glandular parts of the auxiliary copulatory organ possess thick, mostly muscular walls that facilitate the rapid expulsion of mucous substances. These glands elaborate and store apocrinous secretions that composed of mainly glycosaminoglycans and proteins (Panha, 1987; Adamo and Chase, 1990 and Gómez et al., 1996). Gómez (2001) concluded that, while detailed field and laboratory studies are now beginning to address the great diversity in reproductive biology, there are still too few examples of the integrated ecological, physiological, genetic, behavioral and structural approaches necessary to achieve a level of understanding that will assist conservation or management of gastropod population. To our knowledge there is no information about the effect of molluscicidal active compounds on the histological structure of dart gland. The present study revealed different histopathological changes including, irregular thickening in the outer covering layer, thinning of the basement cell layer, atrophy and reduction of number and size of mucus secretory cells, degeneration and focal pigmentation. All these alterations will affect the functions of this gland. This in turn leads to digestion of most allosperm in the bursa copulatrix before they reach the sperm storage organ. This means decreasing the chance of eggs fertilization and reduction of offspring.

Light microscopic analysis in the present study of the kidney of E. vermiculata showed similarity to some extent to that described for other molluscs as Agriolimax reticulates (Runham and Hunter, 1971); Helix pomatia (Newell and Skelding, 1973); Littorina littrea (Marigómez et al., 1990) and Planorbarius corneus (Klobučar et al., 2001). Molluscan kidney consists of a tubule enclosing a luminal cavity derived from the coelom. The nephrocytes lining the luminal surface of the tubule are involved in the secretion of waste and the resorption of metabolites from the urinary fluid (Simkiss and Mason, 1983 and Klobučar et al., 2001). The important feature characterizing molluscan kidney is their ability to produce and excrete solids in the urine in the form of concretions (Doyle et al., 1978 and Angulo and Moya, 1989). After 24h of metaldehyde treatment, remarkable increase in the number and size of concretions in the kidney epithelium was observed compared to that of control snails. The same effect has been observed in the kidney of bivalves under heavy metal stress (Sulina, 1986, 1989; Hemelraad et al., 1990 and Regoli et al., 1992). Also, non metal organic pollutants caused an increase in the number of concretions in the kidneys of the marine prosobranch Littorina littorea (Cajaraville et al., 1990) and in the freshwater snail Planorbarius corneus (Klobučar et al., 2001). Degeneration of some nephrocytes and hyalinization of fibrous connective tissue were observed in the present study. These histopathological alterations in the kidney of E. vermiculata could affect physiological functions of the snail kidney.

In conclusion, this study may help in changing the view of workers in the field of terrestrial gastropods management toward using metaldehyde-based products in snails and slugs control programs in Egypt instead of carbamate insecticides to save non-target organisms in the light of biodiversity conservation.

\section{REFERENCES}

Abdallah, E.A.M., F.A. Kassem and E.A. Kadous, 1992. Laboratory and field evaluation of local bait formulations of certain pesticides against mollusca species. J. Pest Cont. Environ. Sci., 4: 179-92 
Abdallah, E.A.M., F.A. Kassem, H.B. El-Wakil and Y. Abo Bakr, 1998. Molluscicidal potentiality of several pesticides against Eobania Vermiculata and Theba pisana terrestrial snails. Ann. Agric. Sci., 1: 263-76

Abo Bakr, Y., 1997. Toxicological and environmental studies on some terrestrial gastropods. M. Sc. Thesis, Faculty of Agric., Alex. Univ., Egypt

Adamo, S.A. and R. Chase, 1990. The 'love dart' of the snail Helix aspersa injects a pheromone that decreases courtship duration. J. Exp. Zool., 255: 80-7

Adamo, S.A. and R. Chase, 1996. Dart shooting in helicid snails: an ' honest' signal or an instrument of manipulation? J. Theor. Biol., 180: 77-80

Aioub, A.A., S.A. Ismail and A.A. Mohamdein, 2000. Toxicological and histological studies on some pesticidestreated land snails. Proc. I. C. B. S., 1: 19-38

Aly, R.H. and S.H. Sleem, 2000. Ultrastructure studies on the nervous system of the land snail Eobania vermiculata (Gastropoda: Stylommatophora). J. Egyptian Soc. Parasitol. 30: 197-209

Al-Zahaby, A.S., A.H. Abdel-Rehim and A.A. Al-Mahrouki, 1993. Histochemical features of the digestive gland of banded and unbanded phenotypes of the polymorphic land snail, Eobania vermiculata. J. Egyptian Ger. Soc. Zool., 12: $291-310$

Angulo, E. and J. Moya, 1989. Electron microscophcal studies on the renal concretions of the slug Arion ater (Linnaeus, 1758) (Mollusca, Pulmonata). Zool. Anz., 222: 273-80

Babua, A. and D. Skowronsk-Wendland, 1988. Histological and histochemical studies of the digestive system of the slug Deroceras reticulatus (Müller) (Pulmonata). Bull. Soc. Amis Sci. Lett. Ponzan. Ser. D. Biol., 26: 65-72

Banchroft, J.D., A. Stevens and D.R. Turner, 1996. Theory and practice of histological techniques, $4^{\text {th }}$ edition, Churchill Livingstone, London, San Francisco, Tokyo.

Barker, G.M., 2002. Molluscs as crop pests, $1^{\text {st }}$ edition,CAB International

Baur, B., 1988. Repeated mating and female fecundity in the simultaneously hermaphroditic land snail Arianta arbustorum. Invertebrate Reproduction Development, 14: 197-204

Beshr, S.M., 2000. Ecotoxicological studies on two species of snails and associated insects, infesting fruit trees, in three Egyptian governorates. Ph.D. Thesis, Alex. Univ., Egypt

Bishara, S.I., M.S. Hassan and A.S. Kalliny, 1968. Studies on some land snails injurious to agriculture in UAR. Rev. Zool. Bot. Afr. LXXVII, (3-4): 239-59

Boycott, A., 1917. The genitalia of Acanthinula aculeate. Proc. Malacological Soc. Lond., 12: 221-26

Cajaraville, M.P., J.A. Marigómez and E. Angulo, 1990. Ultrastructure study of the short-term toxic effects of naphthalene on the kidney of the marine prosobranch Littorina littorea. J. Invertebr. Pathol., 55: 215-24
Cengiz, E.L., M.Z. Yildirim, B. Otludil and E. Unlu, 2005. Histopathological effects of Thiodan ${ }^{\circledR}$ on the freshwater snail, Galba truncatula (Gastropoda, Pulmonata). J. Appl. Toxicol., 25: 464-69

Chabicovsky, M., W. Klepal and R. Dallinger, 2004. Mechanisms of cadmium toxicity in terrestrial pulmonates: Programmed cell death and metallothionein overload. Environ. Toxicol. Chem., 23: 648-55

Chase, R. and K.C. Blanchard, 2006. The snails' love-dart delivers mucus to increase paternity. Proc. R. Soc. B 273: 1471-5

Coupland, J.B., 1996. The efficacy of metaldehyde formulations against helicid snails: the effect of concentration, formulation and species. BCPC Symp. Proc., 66: 65- 72

Dimitriadis, V.K., 2001. Structure and function of the digestive system of Stylommatophora. In: Barker, G.M. (ed.). The biology of the terrestrial molluscs. pp: 237- 57. CAB International

Doyle, L.J., N.J. Blake, C.C. Woo and P. Yevich, 1978. Recent biogenic phosphorite: concretions in mollusk Kidneys. Science, 199:1431-3

Egonmwan, R.I., 2007. Gross morphology and ultrastructure study of albumen gland of the land snail Archachatina marginata ovum (Pfeiffer) (Pulmonata: Achatinidae). Pakistan J. Biol. Sci., 10: 322-5

El-Okda, M.M.K., 1979. Land snails of economic importance at Alexandria region with some notes on the morphological features, classification, economic damage and population on the ornamental plants. Agric. Res. Rev. 57: $125-31$

El-Okda, M.M.K., 1980. Land snails of economic importance on vegetable crops at Alexandria and neighboring regions. Agric. Res. Rev., 58: $79-86$

El-Shahaat, M.S., Y. Abo Bakr and E.H. Eshra, 2007. Persistence of methomyl and aldicarb as molluscicides in different baits under laboratory and field conditions. $J$. Adv. Agric. Res. 12: 295-302

El-Shahaat, M.S., E.H. Eshra and Y. Abo Bakr, 2009. Evaluation of urea fertilizer in comparison with some conventional pesticides against terrestrial snails in fruit orchards. J. Pest Cont. Environ. Sci. 17: 19-30

Eshra, E.H., 2004. Studies on terrestrial mollusks at some governorates of West Delta with special reference to its integrated management. Ph.D. Thesis, Faculty of Agric., Al-Azhar Univ., Egypt

El-Wakil, H.B., F.A. Kassem, E.A.M. Abdallah and Y. Abo Bakr, 2000. Ecological and biological studies on some terrestrial gastropod species in Alexandria and El-

Beheira, Egypt. Alex. J. Agric. Res. 45: 207- 24

Gimingham, C.T., 1940. Pests of vegetable crops. Annals of Applied Biology, 27: 167-8

Godan, D., 1983. Pest slugs and snails, biology and control, Springer Verlag, Berlin 
Gómez, B.J., 1991. Morphological and histological study of the genital ducts of Cryptazeca monodonta (Pulmonata Orthurethra), with special emphasis on the auxiliary copulatory organ. Zoomorphology, 111: 95-102

Gómez, B.J., 2001. Structure and functioning of the reproductive system. In: Barker, G.M. (ed.). The biology of the terrestrial molluscs. pp: 307-30. CAB International

Gómez, B.J., T. Serrano and E. Angulo, 1996. Morphology and fine structure of the glands of the dart-sac complex in Helicoidea (Gastropoda, Stylommatophora). Invertebrate Reproduction and Development, 29: 47-55

Hamed, S.S., N.E. Abdelmeguid, A.E. Essawy, M.A. Radwan and A.E. Hegazy, 2007. Histological and ultrastructure changes induced by two carbamate molluscicides on the digestive gland of Eobania vermiculata. J. Biol. Sci., 7 : 1017- 37

Haase, M. and B. Baur, 1995. Variation in spermathecal morphology and storage of spermatozoa in the simultaneously hermaphroditic land snail Arianta arbustorum (Gastropoda: Pulmonata: Stylommatophora). Invertebrate Reproduction and Development, 28: 33-41

Heiba, F.N., I.M. Al-Sharkawy and A.A. Al-Batal, 2002. Effects of the insecticide, Lannate, on the land snails, Eobania vermiculata and Monacha contiana, under laboratory conditions. Online J. Biol. Sci. 2: 8-13

Hemelraad, J., H.J. Herwig, E.G. van Donselaar, D.A. Holwerda and D.I. Zandee 1990. Effects of cadmium in freshwater clams II. Ultrastructural changes in the renal system of Anodonta cygnea. Arch. Environ. Contam. Toxicol., 19: 691-8

Henderson, I. and R. Triebskorn, 2002. Chemical control of terrestrial gastropods. In: Barker, G.M. (ed.). Molluscs as crop pests. pp: 1-31. CAB International

Iglesias, J., J. Castillejo and R. Castro, 2003. The effects of repeated applications of the molluscicide metaldehyde and the biocontral nematode Phasmarhabditis hermaphrodita on mollusks, earth worms, nematodes, acarids and collembolans: a two-years study in north-west Spain. Pest Manag. Sci., 59: 1217-24

IPCS, 1996. Environmental Health Criteria 178: Methomyl. Geneva, World Health Organization.

Kassab, A. and H. Daoud, 1964. Notes on biology and control of land snails of economic importance in the U. A. R. Agric. Res. Rev., 42: 77-98

Klobučar, G.I.V., J. Lajtner and R. Erben, 2001. Increase in number and size of kidney concretions as a result of PCP exposure in the freshwater snail Planorbarius corneus (Gastropoda, Pulmonata). Dis. Aquat. Org., 44:149-54

Koene, J.M. and R. Chase, 1998. The love dart of Helix aspersa Müller is not a gift of calcium. J. Moll. Stud., 64:75-80

Koene, J.M. and H. Schulenburg, 2005. Shooting darts: coevolution and counter-adaptation in hermaphroditic snails. BMC Evolutionary Biology, 5:25-38
Landolfa, M.A., D.M. Green and R. Chase, 2001. Dart shooting influences paternal reproductive success in the snail Helix aspersa (Pulmonata Stylommatophora). Behav. Ecol., 12:773-7

Lind, H. 1973. The functional significance of the spermatophore and the fate of spermatozoa in the genital tract of Helix pomatia (Gastropoda: Stylommatophora). J. Zool., 169: 39-64

Marigómez, J.A., M.P. Cajaraville, E. Angulo and J. Moya, 1990. Ultrastructure alterations in the renal epithelium of cadmium-treated Littorina littorea (L). Arch. Environ. Contam. Toxicol., 19: 863-71

Mersal, H.T., 1990. Changes induced in one land snail of agriculture importance in Egypt. M. Sc. Thesis, Faculty of Girls, Ain Shams University

Moore, M.N., 1982. Lysosomes and environmental stress. Mar. Poll. Bull., 13: 42-3

Moore, M.N., 1985. Cellular responses to pollutants. Mar. Poll. Bull., 16 :134-9

Ministry of Agriculture and Land Reclamation, 2001. Technical recommendations for agricultural pests control. pp. 180-184

Newell, P.F. and J.M. Skelding, 1973. Studies on the permeability of the septate junction in the kidney of Helix pmatia L. Malacologia, 14: 81-91.

Panha, S. 1987. Histochemical and ultrastructural studies on the amatorial organ of Hemiplecta distincta (Pfeiffer) (Pulmonata: Ariophantidae). Venus, 46:108-15

Radwan, M.A., A.E. Essawy, N.E. Abdelmeguid, S.S. Hamed, A.E. Ahmed, 2008. Biochemical and histochemical studies on the digestive gland of Eobania vermiculata snails treated with carbamate pesticides. Pestic. Biochem. Physiol., 90: 154-67

Regoli, F., M. Nigro and E. Orlando, 1992. Effects of copper and cadmium on the presence of renal concretions in the bivalve Donacilla cornea. Comp. Biochem Physiol., 102C: $189-92$

Rogers, D. and R. Chase, 2001. Dart receipt promotes sperm storage in the garden snail Helix aspersa. Behav. Ecol. Sociobiol., 50: 122-7

Runham, N.W. and P.J. Hunter, 1971. Terrestrial slugs, $1^{\text {st }}$ edition, Hutchinson and Co., London

Saad, A.M. and E.A.S. Farag, 1988. Morphological studies on the digestive system of the land snail, Eobania vermiculata (Müller) Gastropoda: Stylommatophora). Alex J. Agric. Res., 33: 311-26

Simkiss, K. and A.Z. Mason, 1983. Metal ions: Metabolic and toxic effects. In: Hochachka. P.W. (ed.). The mollusca, Vol 2, Environmental biochemistry and physiology. pp: 101-64. Academic Press Inc, New York

Snyman, R.G., A.J. Reinecke and S.A. Reinecke, 2005. Quantitative changes in the digestive gland cells of the snail Helix aspersa after exposure to the fungicide copper oxychloride. Ecotoxicol. Environ. Safety, 60: 47-52

Speiser, B and C. Kistler, 2002. Field tests with a molluscicide containing iron phosphate. Crop Protection, 21: 389-94 
Sulina, I., 1986. Histopathological changes in the mussel Mytelus edulis L. at the outlet from titanium dioxide plant in Northern Baltic. Ann. Zool. Fenn., 23: 61-70

Sulina, I., 1989. Cystic kidneys in copper exposed mussels. Dis Aquat. Org., 6: 63-6

Sumner, A.T., 1965. The cytology and histochemistry of the digestive gland cells of Helix. Quart. I. Micr. Sci., 106:173-92

Sumner, A.T., 1969. The distribution of some hydrolytic enzymes in the cells of the digestive gland of certain lamellibranchs and gastropods. J. Zool., 158: 27791

Triebskorn, R., 1991. The impact of molluscicides on enzyme activities in the hepatopancreas of Deroceras reticulatum (Müller). Malacologia, 33: 255-72

Triebskorn, R. and C. Künast, 1990. Ultrastructure changes in the digestive system of Deroceras reticulatum (Mollusca; Gastropoda) induced by lethal and sublethal concentrations of the carbamate molluscicide Cloethocarb. Malacologia, 32: 89-106
Triebskorn, R., K. Christensen and I. Heim, 1998. Effects of orally and dermally applied metaldehyde on mucus cells of slugs Deroceras reticulatum depending on temperature and duration of exposure. J. Moll. Stud., 64: 467-87

Walker, G., 1970. The cytology, histochemistry and ultrastructure of the cell types found in the digestive gland of slug, Agriolimax reticulates (Müller). Protoplasma, 71: 91-109

Zaalouk, M.A., 2003. Toxicological studies on some economic animal pests. Ph.D. Thesis, Alexandria. Univ., Egypt

Zaldibar, B., I. Cancio and I. Margomez, 2007. Reversible alterations in epithelial cell turnover in digestive gland of winkles (Littorina littorea) exposed to cadmium and their implications for biomarker measurements. Aquat. Toxicol., 81:183-96

Zedan. H.A., A. Saleh and S.M. Ali, 1999. Bactericidal activity of Bacillus thuringiensis against snails, toxicological and histological studies. The $2^{\text {nd }}$ International Conf. of Pest Control. pp: 489-497. Mansoura, Egypt 


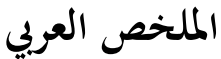

\section{التغيرات النسيجية المرضية بواسطة مبيد الميتالدهيد في قوقع إيوبانبا فيرميكيولاتا}

$$
\text { ياسر أبو بكر }
$$

للطبقة العضلية الخارجية، ترقق الطبقة القاعدية، وضمور وتحلل الخلايا

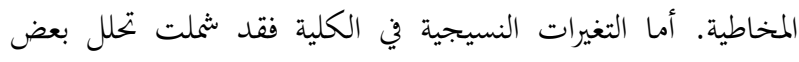
الخلايا الإخراجية وزيادة حجم وعدد الأجسام المتحجرة داخل الخلايا

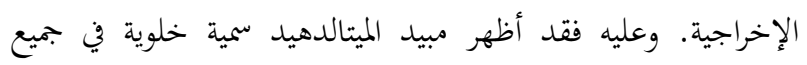
الأنسجة التي تم فحصها مما يؤدي إلى فشل أنظمة الهضم والتناسل فيله والإخراج ومن ثم موت الكائن المستهدف.
في هذه الدراسة تم فحص التغيرات النسيجية المرضية الحادثة

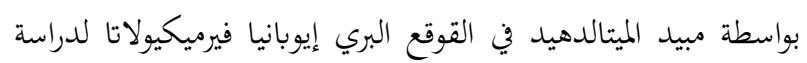

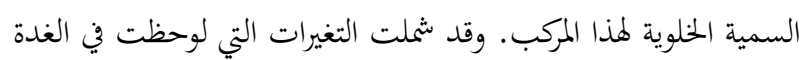

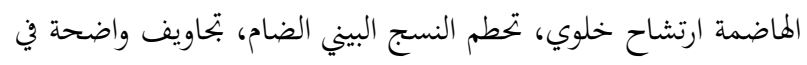

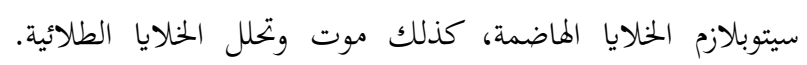
والتغيرات النسيجية الحادثة في غدة السهم شملت تغلظ غير منتظم 